
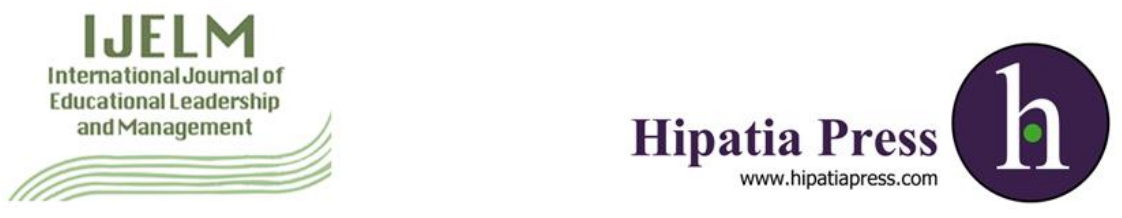

Instructions for authors, subscriptions and further details:

http://ijelm.hipatiapress.com

\title{
Relation between School Managers and Teachers Downward and Upward Influence Tactics and Organizational Justice
}

Saadet Kuru Cetin ${ }^{1}$ \& Şakir Çınkır²

1) Muğla University. Turkey

2) Ankara University. Turkey

Date of publication: July $16^{\text {th }}, 2018$

Edition period: January 2018-July 2018

To cite this article: Kuru, S. \& Cinkir, S. (2018). Relation between School Managers and Teachers Downward and Upward Influence Tactis and Organizational Justice. International Journal of Educational Leadership and Management, 6(2), 126-153. doi: 10.17583/ijelm.2018.3359

To link this article: http://dx.doi.org/10.17583/ijelm.2018.3359

\section{PLEASE SCROLL DOWN FOR ARTICLE}

The terms and conditions of use are related to the Open Journal System and to Creative Commons Attribution License (CCAL). 


\section{Relation between School Managers and Teachers Downward and Upward Influence Tactics and Organizational Justice}

Saadet Kuru Cetin

Muğla University
Şakir Çınkır

Ankara University

\section{Abstract}

In this study, it was aimed to determine how the secondary school administrators and teachers influence each other and their perceptions of the types of organizational justice. It was also tested whether the types of organizational justice predict the organizational influence strategies or not.

The data were collected from 284 school administrators and 854 teachers. According to the results of the study, while teachers highly use friendliness, bargaining and assertiveness tactics to influence their managers, they use higher authority and coalition tactics at a moderate level. The teachers use reasoning tactics the least. On the other hand, school administrators use friendliness, bargaining and coalition tactics highly, higher authority and sanction tactics at a moderate level and reasoning tactics the least. The results also showed that from among the types of organizational justice, the distributive justice, procedural justice and interactional justice predict the organizational influence strategies of the teachers and the school administrators to the greatest extent.

Keywords: school managers, teachers, influence tactics, organizational justice 


\section{Relación entre Directores Escolares y \\ Profesores: Tácticas de influencia hacia}

\section{abajo y hacia arriba y justicia organizacional}

Saadet Kuru Cetin

Muğla University
Şakir Çınkır

Ankara University

\section{Resumen}

En este estudio, el objetivo fue determinar cómo los directores y maestros de Educación Secundaria se influyen mutuamente y sus percepciones sobre los tipos de justicia organizacional. También se probó si los tipos de justicia organizacional predicen las estrategias de influencia organizacional o no.

Los datos fueron recolectados de 284 directores escolares y 854 maestros. De acuerdo con los resultados del estudio, mientras que los maestros usan altamente las tácticas de amistad, regateo y asertividad para influenciar a sus directores, ellos usan una autoridad más alta y tácticas de coalición en un nivel moderado. Los maestros usan menos tácticas de razonamiento. Por otro lado, los directores escolares usan tácticas de amistad, negociación y coalición, una autoridad más alta y tácticas de sanción a un nivel moderado y tácticas de razonamiento en menor medida. Los resultados también mostraron que, entre los tipos de justicia organizacional, la justicia distributiva, la justicia procesal y la justicia interaccional predicen las estrategias de influencia organizacional de los maestros y los directores en la mayor medida posible.

Palabras clave: directores escolares, maestros, tácticas de influencia, justicia organizacional 


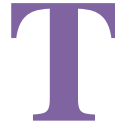

he process of influence is an important factor in terms of managers and personnel. When we address the process of influence in relation to educational organizations which are social systems highly dependent on human labour and having a complex structure (Bursalioglu, 2002, 92).

Two of the concepts most influential on the strength of influence to be induced are power and authority. Even though all social organizations try to exercise some control on their members, control is of vital importance for official organizations and the main means of imposing control is having power (Hoy and Miskel, 2010, 203). The concept of power is a concept used to understand how individuals within the organization affect each other (Mintzberg, 1983; Pfeffer, 1999; Yukl, 2010). In the simplest terms, power can be defined as" the ability to influence others", "the capacity to influence behaviors of others" (Hunt, 1994, 38) or "a means of achieving the objectives" (Bursalioglu, 2002).

Authority is a concept which is closely affiliated with power. Even if power and authority are used interchangeably in the articles of Hatch (1997, 284) and Rollinson $(2002,404)$, these two concepts are completely different from each other. According to Bayrak (2000, 28), authority is the legal version of power and it is required for social organizations to sustain their existence and can be construed as a natural result of the existence of governing and governed relationship. Authority is a special version of power gained by the person depending on what position he/she occupies (Hatch, 1997, 284) or the role he/she plays (Rollinson, 2002,404) in the organization and this special position emerging within the organization includes rights, privileges, obligations and duties (Yukl, 2010, 199). The individual with power is expected and required to use authority in social concept since power is legalized within the organization (Weber, 1947).

Influence is one of the other terms intertwining with the concept of power (Alonso, 2010, 24; Hales, 1993, 19). A few researchers (e.g., Yang \& Cervero, 2001) have used the two terms--power and influence. For example, Mechnic (1962) considered power, influence, and control as synonymous. In the same vein, other researchers (Salancik \& Pfeffer, 1977) have defined power and influence as synonyms and used interchangeably. 
The concept of power and influence preoccupied the minds of Machiavelli (1998) and Weber (1947). To Bass (1990), power and influence are the two concepts that are widely used in leadership and organization studies.

Influence is a process that has been engaged in by the person while using his/her power (Bayrak, 2000, 31). While Bursalıglu (2002) asserts that power understandably has an ability to influence the human, Greenberg and Baron (1993) define power as a capacity to influence the attitude and behaviors of others in a demanded way. Hales (1993), Bacharach and Lawler (1982) separate power and influence from each other; power being a source and influence being an attempt to change the behaviors of others by manipulating the source of power. French and Raven (2001) define influence as the way of leading to change in behaviors, attitudes and values of others by exercising force on them.

All attempts of influence may not create the expected effect. One of the reasons determining the success in the process of manager influence on personnel is the willingness of personnel to fulfill their duties and responsibilities and to achieve organizational objectives. To Saritas (1991, 3 ), all types of behaviors exhibited in the process of management are the influence behavior shown by the manager and successful managers are required to influence the personnel. The management depends on the influence. As Dawis (1984) stated, if a manager is good at coordination, provides consultancy and presents the objectives in such a convincing way that the personnel feel the desire to contribute to them, then it can be said that he/she influences the personnel. To Basaran $(2000,99)$, influence is the process in which one person sets other person into motion. What's more, influence is defined as the process of motivating the personnel to work and orienting their activities in the desired direction (Massie, 1983, 96).

Even if the concept of influence dates back to ancient times, the history of studies of the process of influence examining the relationship between the manager and personnel is not that old. Some researchers (Friedrich, 2010; Yukl, 2010) describe the concept of influence as an important part of 
leadership research. All leaders influence the people one way or another (Friedrich, 2010, 1). A leader or a manager is required to use some tactics to influence other people. Organizational influence tactics have a mutual relationship between the manager and audience. Managers are required to put across their ideas, apply their policies, motivate their personnel, support them and make their decisions to be adopted by the personnel (Duyar, Aydin and Pehlivan 2009, 192). Besides, not only top down influence but also bottom up influence attract attention as an interest and researched topics at conceptual level (Dohlen, 2012; Yukl and Tracey, 1992; Schriesheim and Hinkin, 1990). Organizational influence tactics applied by the personnel in the bottom up level create important effects on administrative decisions by influencing the perceptions and impressions of the managers; thus, can play an important role in organizational activities (Yaylac1, 2006, 95).

Another concept of interest to the current research is organizational justice, which refers to how justice is perceived by the personnel within the organization (Greenberg, 1990; Moorman, 1991; Ozmen et al., 2005; İsbas1, 2000, Polat, 2008). Basaran (2000, 15) defines organizational justice as giving rights to personnel at the rate of their contribution to the organization and penaliing them at the rate of their actions against the rules. Greenberg (1990) asserts that organizational justice is related to personnel's beliefs about how just they are treated within the organization and suggests that this justice perception influences the business outputs of the personnel such as commitment, job satisfaction and work satisfaction.

Social interactions of teachers and managers are highly important in the school which is a social system. Managers and teachers try to influence each other with different actions and behaviors. As Bursalioglu $(2002,120)$ states, the target of the influence is the decision making and in that sense influence is more about the physiology of the organization rather than its anatomy. Any attempt of a school manager made in the way of influencing the organization and personnel requires knowledge about management sciences as well as social sciences. As in other organizations, it is expected that there is a relation between the organizational influence tactics and organization justice in secondary education (Massey and Dawes, 2006; Yamaguchi, 2009, 22). The reason why this relation is important is that fair school environment 
132 Kuru \& Cinkir - Relation between School Managers and Teachers Downward and Upward Influence Tactics and Organizational Justice

enhances the educational success and makes personnel more happy and peaceful within the school.

\section{Research Problem}

The current study aims at examining the relationship between Turkish secondary school administrators and teachers influence each other and their perceptions towards the types of organizational justice.

More specifically, the present study addresses the following research questions:

1) What is the relationship between Turkish secondary school administrators' organizational influence tactics (i.e. Friendliness, Reason, Bargain, Sanctions, Assertiveness, Higher Authority, Coalition) and organization justice (i.e. distributive justice, procedural justice, interactional justice and rectificatory justice)

2) What is the relationship between Turkish secondary school teachers' organizational influence tactics (i.e. Friendliness, Reason, Bargain, Assertiveness, Higher Authority, Coalition) and organization justice (i.e. distributive justice, procedural justice, interactional justice, and rectificatory justice)

\section{Methodology}

\section{General Background of Research}

In this study, it was aimed to determine how the secondary school administrators and teachers influence each other and their perceptions of the types of organizational justice. It was also tested whether the types of organizational justice predict the organizational influence strategies or not. 


\section{Participants}

Two groups of participants were used in this study (teacher and school administrators). The data were collected from 284 school administrators and 854 teachers. The sample of the study consisted of secondary school administrators and teachers working at Istanbul, Tekirdag, Balıkesir, İzmir, Mugla, Bursa, Kocaeli, Konya, Karaman, Adana, Hatay, Kırsehir, Kırıkkale, Zonguldak, Samsun, Trabzon, Ordu, Erzurum, Agr1, Malatya, Mus, Gaziantep and Diyarbakır city centers, Turkey.

\section{Instrument and Procedures}

Data collection tool that consists of two parts was used in order to determine teacher and school administrators' organizational influence tactics and perceptions of organizational justice. Fist part of survey has six questions related to demographics. Second part of survey has two main assessment tools including Profiles of Organizational Influence Strategies (POIS) and Organizational Justice Type Scale.

\section{Research Instrument and Procedure}

Profiles of Organizational Influence Strategies (POIS). POIS was used to assess school administrators' and teachers' influence strategies. This instrument provides a profile of strategies. POIS, a five- point Likert scale ranging from " $1=$ never to $5=$ almost always". Having obtained the permission, the instruments, being used in this study, are POIS Influence Strategies Scale of Schmid and Kipnis. Profiles of Organizational Influence Strategies (POIS): Influencing Your Manager (Form M) are classified under seven categories, named as: Friendliness, Reason, Sanction, Higher authority, Assertiveness, Coalition and Bargain. Each influence tactics are measured by two to six items (Kipnis \& Schmidt, 1999). The scale is composed of a total of 27 questions.

Profiles of Organizational Influence Strategies (POIS): Influencing Your Subordinates (Form S)] are classified under six categories, named as: Friendliness, Reason, Higher authority, Assertiveness, Coalition and 
Bargain. Each influence tactics are measured by two to seven items. The scale is composed of a total of 33 questions.

Profiles of Organizational Influence Strategies scale consist of two different forms that separately applied school administrators and teachers. Organizational influence strategies profile: influencing manager (Form Y) after DFA investigation of the 27 items six factors structure, it was concluded that the measurement model was appropriate. According to that, organizational influence strategies scale: 27 items (article) 6 factors influencing manager's scale (Form Y) statistical value is Chi-square $(\mathrm{X}=493,78 ; \mathrm{P}=0,000 \mathrm{sd}=283$ ) adjustment index $\mathrm{CFI}=0,97, \mathrm{NNFI}=0,96$, $\mathrm{GFI}=0,76$ AGFI $=0,71$ and $\mathrm{RMSEA}=0,055$. Organizational influence strategies profile: Influence the subordinate (Form $\mathrm{S}$ ) profile is proved to be an appropriate pattern (model) after the examination of DFA structure with six factors and 33 items that emerged from the original profile. According to that, organizational influencing strategies profile: statistics of influencing subordinate profile with 33 items and 7 factors are Chi-square $(X=808,53$; $\mathrm{P}=0,000, \mathrm{sd}=474), \mathrm{CFI}=0,97, \mathrm{NNFI}=0,97, \mathrm{GFI}=0,70, \quad \mathrm{AGFI}=0,65$ and $\mathrm{RMSEA}=0,06$.

Organizational justice type scale. In this part of the study, in order to state whether factor structure of Organizational justice type is appropriate or not, exploratory factor analysis (EFA) and confirmatory factor analysis (DFA) were done. Organizational justice type scale was used to assess school administrators' and teachers' organizational justice. Organizational justice type scale, a five- point Likert scale ranging from ${ }^{*} 1=$ never to $5=$ almost always." The Organizational justice type Scale consists of distributive justice, procedural justice, interactional justice and rectificatory justice subscales. The EFA structures for Organizational justice type subscales are reported in Table 1. 
Table 1

Results of the Factor Analysis of the Organizational justice type scale

\begin{tabular}{|c|c|c|c|c|}
\hline $\begin{array}{l}\text { Organizational } \\
\text { justice type scale }\end{array}$ & $\begin{array}{l}\text { Kaiser-Meyer- } \\
\text { Olkin (KMO) } \\
\text { measur }\end{array}$ & $\begin{array}{l}\text { Factor } \\
\text { structure }\end{array}$ & $\begin{array}{l}\text { Percent } \\
\text { of the } \\
\text { variance }\end{array}$ & $\begin{array}{c}\text { Cronbach } \\
\text { Alfa }(\alpha)\end{array}$ \\
\hline $\begin{array}{l}\text { Distributive justice } \\
\text { subscales }\end{array}$ & 0,923 & Single Factor & $\% 51,91$ & 0,893 \\
\hline $\begin{array}{l}\text { Procedural justice } \\
\text { subscales }\end{array}$ & 0,958 & Single Factor & $\% 56,96$ & 0,911 \\
\hline $\begin{array}{l}\text { Interactional justice } \\
\text { subscales }\end{array}$ & 0,966 & Single Factor & $\% 71,00$ & 0,958 \\
\hline $\begin{array}{l}\text { Rectificatory justice } \\
\text { subscale. }\end{array}$ & 0,920 & Single Factor & $\% 53,52$ & 0,873 \\
\hline
\end{tabular}

Distributive justice subscale after DFA investigation of the 6 items (articles) six factors structure, it was concluded that the measurement model was appropriate. 6 items one factors distributive justice subscale statistical value is Chi-square $(\mathrm{X}=16,17 ; \mathrm{P}=0,000 \mathrm{df}=14)$ adjustment index $\mathrm{CFI}=0,99$, $\mathrm{NNFI}=0,99, \mathrm{GFI}=0,96 \mathrm{AGFI}=0,91$ and $\mathrm{RMSEA}=0,040$. Procedural justice subscale after DFA investigation of the 13 items (articles) six factors structure, it was concluded that the measurement model was appropriate. 13 items one factors procedural justice subscale statistical value is Chi-square $(\mathrm{X}=168 ; \mathrm{P}=0,000 \mathrm{df}=65)$ adjustment index $\mathrm{CFI}=0,98, \mathrm{NNFI}=0,97, \mathrm{GFI}=0,89$ $\mathrm{AGFI}=0,84$ and RMSEA=0,089. Interactional justice subscale after DFA investigation of the 6 items (articles) six factors structure, it was concluded that the measurement model was appropriate. 11 items one factors interactional justice subscale statistical value is Chi-square ( $X=83,09$; $\mathrm{P}=0,000 \mathrm{df}=43$ ) adjustment index $\mathrm{CFI}=0,99, \mathrm{NNFI}=0,98, \mathrm{GFI}=0,93$ AGFI $=0,89$ and RMSEA=0,068. Rectificatory justice subscale after DFA investigation of the 6 items (articles) six factors structure, it was concluded that the measurement model was appropriate. 8 items one factors rectificatory justice subscale statistical value is Chi-square (X2=38,97; $\mathrm{P}=0,000 \quad \mathrm{df}=20$ ) adjustment index $\mathrm{CFI}=0,99, \mathrm{NNFI}=0,98, \mathrm{GFI}=0,95$ $\mathrm{AGFI}=0,92$ and RMSEA=0,069. 
136 Kuru \& Cinkir - Relation between School Managers and Teachers Downward and Upward Influence Tactics and Organizational Justice

\section{Data Analysis}

In order to determine the organizational influence tactics of the teachers and administrators the arithmetic means and standard deviations were calculated with the purpose of identifying a) friendliness, b) reason, c) bargain, d) coalitions, e) assertiveness, f) higher authority and g) sanction subdimensions which are regarded as sub-dimensions in the influence tactics of administrators as different from the organizational influence tactics of teachers. In order to determine the teachers' views on the dimensions of a) distributive justice, b) procedural justice, c) interactional justice and d) rectificatory justice in terms of teacher's organizational justice perceptions, the arithmetic means and standard deviations were calculated.

In order to determine whether teachers' and administrators' organizational influence tactics are predicted by organizational justice types such as distributive justice, procedural justice, interactional justice and rectificatory justice, regression analysis was carried out.

\section{Results and Discussion}

\section{Findings and Interpretation related to the Prediction of Teachers' Influence Tactics}

The regression analysis results on how independent variables; distributive justice (DJ), procedural justice (PJ), interactional justice (IJ) and rectificatory justice $(\mathrm{RJ})$, which are types of teachers' organizational justice directly or indirectly affect organizational influence tactics have been presented below.

The arithmetic means, standard deviations and correlation values related to teachers' organizational influence tactics (IT) and independent variables of distributive justice (DJ), procedural justice (PJ), interactional justice(IJ) and rectificatory justice (RJ) have been presented in Table 2. 
Table 2.

The Arithmetic Means, Standard Deviations and Correlation Values Related to Independent and Dependent Variables

\begin{tabular}{lllllllll}
\hline Variable & $\mathrm{N}$ & $\mathrm{X}$ & $\mathrm{sd}$ & & \multicolumn{2}{c}{$\mathrm{r}$} & $\mathrm{IJ}$ \\
\hline IT & 859 & 20,757 & 6,93 & 1 & & & & \\
DJ & 860 & 42,254 & 11,66 & 0,189 & 1 & & & \\
PJ & 860 & 38,991 & 10,87 & 0,185 & 0,809 & 1 & & \\
IJ & 860 & 26,447 & 7,47 & 0,139 & 0,708 & 0,903 & 1 & \\
RJ & 854 & 64,353 & 15,08 & 0,155 & 0,748 & 0,898 & 0,897 & 1 \\
\hline
\end{tabular}

Influence Tactics (IT); Distributive justice (DJ), procedural justice (PJ), interactional justice (IJ) and rectificatory justice (RJ)

As it can be seen in Table 2, it has been determined that there is a correlation with the value of 0.19 between organizational influence tactics and distributive justice, a correlation with the value of 0.19 with procedural justice, a correlation with the value of 0.14 with interactional justice and a correlation with the value of 0.15 with rectificatory justice.

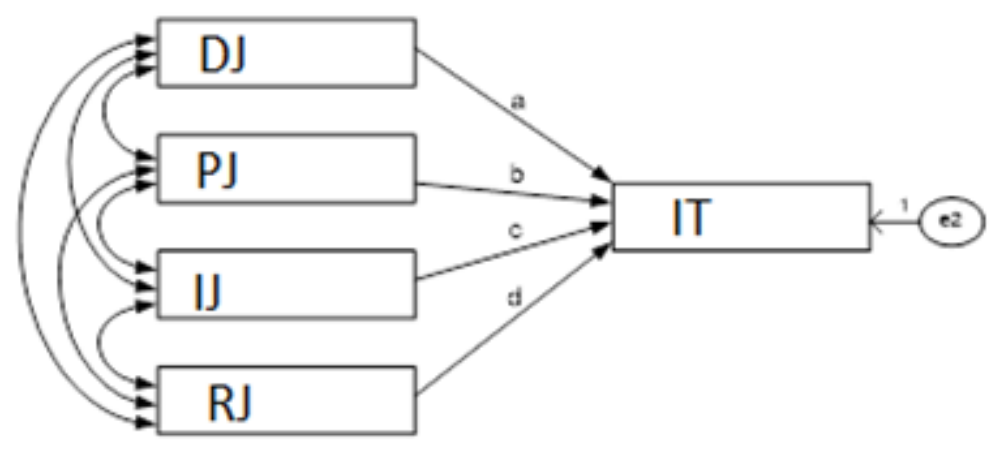

Figure 1 Conceptual model with significant path coefficient 
Taking this as a starting point, the conceptual regression model (Figure 1) was formed to determine whether the organizational influence tactics used by teachers significantly predict their perception scores of distributive justice, procedural justice, interactional justice and rectificatory justice in and the results of the regression model have been presented below (Figure 2 and Table 2).

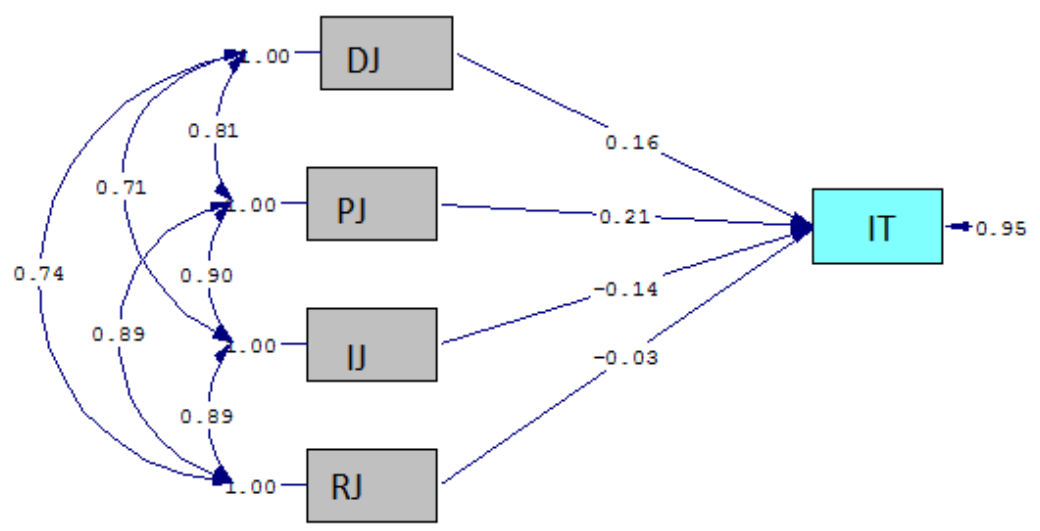

Chi-Square $=0.00, d f=0, P-$ value $=1.00000$, RMSEA $=0.000$

Figure 2 The Standardized Regression Values of The Regression Model

In Figure 2, the standardized regression values of the regression model's perception scores of distributive justice, procedural justice, interactional justice and rectificatory justice in accordance with the organizational influence tactics used by teachers have been given. In the path analysis, the standardized regression coefficients show the direct effect of independent variables on the dependent variables. The standardized regression coefficient is the same with the $\beta$ coefficient in multiple regression. The standardized regression coefficient and $\beta$ coefficient are applied to determining variables which are measured as Z-score (Thompson, 2004, 16). The relative order of significance of variables predicted in accordance with the standardized regression values on organizational 
influence tactics can be seen in Figure 14 as procedural justice $(0,21)$, distributive justice $(0,16)$, interactional justice $(-0,14)$ and rectificatory justice $(-0,03)$.

Table 3

Organizational Influence Tactics of Teachers, Regression Model Formed Organizational Justice Types

\begin{tabular}{lccc}
\hline Regression Model & B & $\beta$ & $t$ \\
\hline IT (D) <--- DJ (P) & 0,35 & 0,16 & 2,86 \\
IT (D) <--- PJ (P) & 0,27 & 0,21 & 2,17 \\
IT (D) <--- IJ (P) & $-0,19$ & $-0,14$ & $-1,61$ \\
IT (D) <--- RJ (P) & $-0,06$ & $-0,03$ & $-0,39$ \\
\hline & $*$ P < $05,(P)=$ Predictive , (D)=Dependent
\end{tabular}

When we take a look at the standardized regression significance $(\beta)$ obtained from the regression model in Table 2 and non-standardized regression significance in Table 3 (B) and the $\mathrm{P}$ and $\mathrm{t}$ values, it can be seen that in predicting the organizational influence tactics, primarily distributive justice (DJ) $(B=0,35, \beta=0,16, P<0,05, t>1,96)$ and procedural justice (PJ) $(\mathrm{B}=0,27, \beta=0,21, \mathrm{P}<0,05, \mathrm{t}>1,96)$ are effective. It is observed that these two variables significantly predict the organizational influence tactics and are effective in the use of organizational influence tactics. When interactional justice (IJ) ( $\mathrm{B}=-0,19 ; \quad \beta=-0,14, \quad \mathrm{P}>0,05, \mathrm{t}<1,96)$ and rectificatory justice $(\mathrm{RJ})(\mathrm{B}=-0,06, \beta=-0,03, \mathrm{P}>0,05, \mathrm{t}<1,96)$ are considered together with the other two variables, it is seen that these do not directly predict influence tactics in a significant manner.

Therefore, the Path between rectificatory justice RJ (D) <--- IJ(P) which does not have a statistically significant effect on organizational influence tactics and has the smallest regression values has been equated to 0 , a second regression model has been formed and the new regression model has been tested again. Table 2 below shows regression model 1 and the $\mathrm{X}^{2}$, RMSEA, $\mathrm{CFI}$ and df values related to the newly formed regression model. 


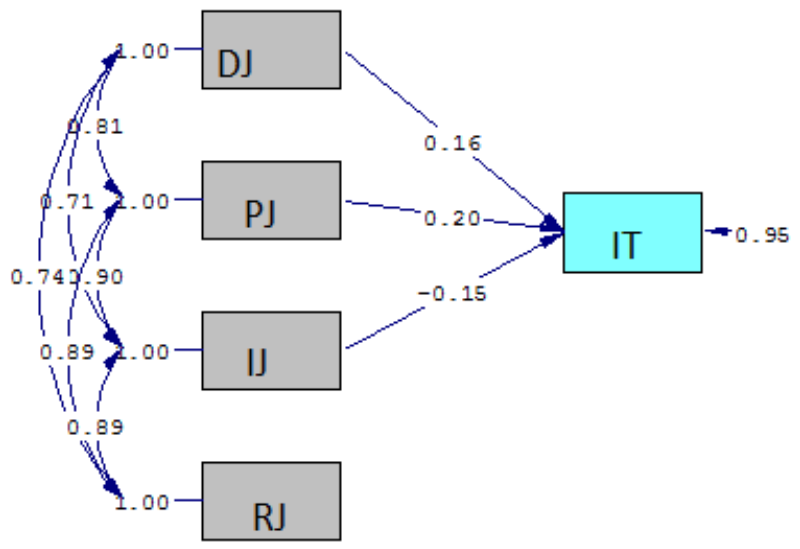

Chi-Square=0.15, df=1, P-value $=0.69623, \mathrm{RMSEA}=0.000$

Figure 3. The Standardized Regression Values of the Regression Model

As it can be seen in Figure 3, after the Path between rectificatory justice and interactional justice has been equated to 0 , the standardized regression values of the regression model's perception scores of distributive justice, procedural justice and interactional justice have been given. According to the standardized regression values, the relative order of significance of predictive variables on organizational influence tactics being procedural justice $(0,20)$, distributive justice $(0,16)$ and interactional justice $(-0,15)$ can be seen in Figure 17.

Table 4.

Resulting Fit Indices for Regression Model

\begin{tabular}{lccccccc}
\hline Regression Model & $\mathrm{X}^{2}$ & $\mathrm{sd}$ & $\mathrm{p}$ & $\mathrm{CFI}$ & $\mathrm{RMSEA}$ & $\Delta \mathrm{X}^{2}$ & $\Delta \mathrm{SD}$ \\
\hline 1.Model (Regression Model) & 0,00 & 0,00 & 1 & 1,00 & 0,00 & & \\
2. Model (c path =0) & 0,15 & 1 & 0,69 & 1,00 & 0,00 & 0,15 & 1 \\
\hline
\end{tabular}

In Table 4, the two regression models have been tested with the chisquare test and when the optimality concordance index values of the second 
regression model are analyzed, it has been seen that the second model is an acceptable model. It has been observed that rectificatory justice does not have a direct effect on the organizational influence tactics. It is seen that the other three variables explain $5 \%$ of the organizational influence tactics. According to the results of the regression analysis in the Path analysis, the regression equality (mathematical model) related to the prediction of the organizational influence tactics has been presented below.

Table 5.

Organizational influence tactics of administrators, the regression equality (mathematical model) formed organizational justice

$\mathrm{IT}=\quad 0,35 * \mathrm{DJ}+\quad 0,25 * \mathrm{PJ} \quad-0,21 * \mathrm{IJ} \quad \begin{gathered}\text { Standard } \\ \text { Errors }=\end{gathered} \quad 221,39, \quad \mathrm{R}^{2}=0,051$

Standard

Errors

$(0,12)$

$(0,12)$

$(0,11)$

$(10,71)$

t value

2,83

2,16

$-1,99$

20,68

Teachers' organizational justice types; distributive justice and procedural justice, affect the organizational influence tactics in a positive manner and interactional justice and organizational influence tactic in a negative manner. $35 \%$ of the organizational influence tactics is explained by distributive justice, $25 \%$ is explained by procedural justice and $21 \%$ is explained by interaction justice. These three variables together explain 5\% of the organizational influence tactics. According to these results, it can be stated that it has "little" effect in explaining distributive justice, procedural justice and organizational influence tactics.

The results of the studies of Yamaguchi (2009), Yamaguchi (2005) and Dulebohn and Ferris (1999) support the results of the study. Dulebohn ve Ferris (1999), in their study in which they analyzed the relationship between administrators and employees, organizational influence tactics and procedural justice, have concluded that there is a negative significant relationship between organizational influence tactics and procedural justice $((-0,35)$. In the Dulebohn and Ferris (1999) study, the different results on the 
relationship between organizational influence tactics and procedural justice being different from the results of this study is due to regarding the study in terms of performance evaluation. However, the study is important in terms of having a very close result with the relationship $(0,19)$ obtained in this study on the effect of procedural justice on interaction justice.

Yamaguchi's (2009) study on American and Japanese employees has analyzed the effect of organizational influence tactics (rational, mild and severe) on procedural justice. In the United States of America and Japan samples, it has been concluded that all of the mild and severe organizational influence tactics predict procedural justice. In the USA sample, it has been concluded that the standardized regression values show that rational tactics have an effect of 0,77 on procedural justice, $-0,02$ on mild organizational influence tactics and $-0,27$ on severe organizational influence tactics. In the Japan sample, it has been concluded that the standardized regression values show that rational tactics have an effect of 0,66 on procedural justice, 0,02 on mild organizational influence tactics and 0,07 on severe organizational influence tactics (Yamaguchi 2009).

Yamaguchi (2005) in his study on Japanese employees has concluded that in the model formed on organizational influence tactics, perceived procedural justice and variability of career stability, procedural justice explains $27 \%$ of interpersonal organizational influence tactics. In the study, it is seen from the results of the correlation table that mild influence tactic is related to interpersonal influence tactic with 0,31 , rational influence tactic with 0,31 and severe influence tactic with $-0,26$. Similar findings had been obtained in Yamaguchi's (2004, cited in Yamaguchi, 2009, 23) previous study conducted in Japan.

Bradway (2002) in his study has concluded that the perception of justice in employees who use positive influence tactics is higher in comparison to employees who use negative influence tactics. Dulebohn's (1995) study on administrators and employees concludes that there is a relationship of 0.19 between the procedural justice perceived by employees and organizational influence tactics. However, Dulebohn (1995) has reported 
that there is no relationship between distributive justice and organizational influence tactics.

According to the results of this study and literature analysis, it has been concluded that there is a relationship between organizational justice types and organizational influence tactics. However, as it can be understood from these results as well, the findings show that the relationship between organizational influence tactics and organizational justice types is not very strong.

\section{Findings and Interpretation on the Prediction of Administrators' Influence Tactics}

The regression analysis results on how independent variables; distributive justice (DJ), procedural justice (PJ), interactional justice(IJ) and rectificatory justice $(\mathrm{RJ})$, which are types of administrators' organizational justice, directly or indirectly affect organizational influence tactics have been presented below.

The arithmetic means, standard deviations and correlation values related to administrators' organizational influence tactics (IT) and independent variables; distributive justice (DJ), procedural justice (PJ), interactional justice(IJ) and rectificatory justice (RJ) have been presented in Table 6.

Table 6.

The Arithmetic Means, Standard Deviations and Correlation Values Related To Independent and Dependent Variables

\begin{tabular}{lccclllll}
\hline Variables & \multirow{2}{*}{$\mathrm{N}$} & $\mathrm{X}$ & $\mathrm{sd}$ & $\mathrm{IT}$ & $\mathrm{DJ}$ & $\mathrm{PJ}$ & $\mathrm{IJ}$ & $\mathrm{RJ}$ \\
\hline IT & 283 & 84,81 & 16,66 & 1 & & & & \\
DJ & 283 & 23,54 & 5,08 &, 241 & 1 & & & \\
PJ & 283 & 53,43 & 8,96 &, 170 &, 478 & 1 & & \\
IJ & 283 & 46,10 & 7,86 &, 143 &, 390 &, 897 & 1 & \\
RJ & 284 & 30,62 & 5,49 &, 206 &, 540 &, 749 &, 763 & 1 \\
\hline
\end{tabular}

As seen in Table 6, it has been determined that there is a 0,24 relationship between organizational influence tactics and distributive justice, 
144 Kuru \& Cinkir - Relation between School Managers and Teachers Downward and Upward Influence Tactics and Organizational Justice

0,21 with rectificatory justice, 0,17 with procedural justice and 0,14 with interaction justice.

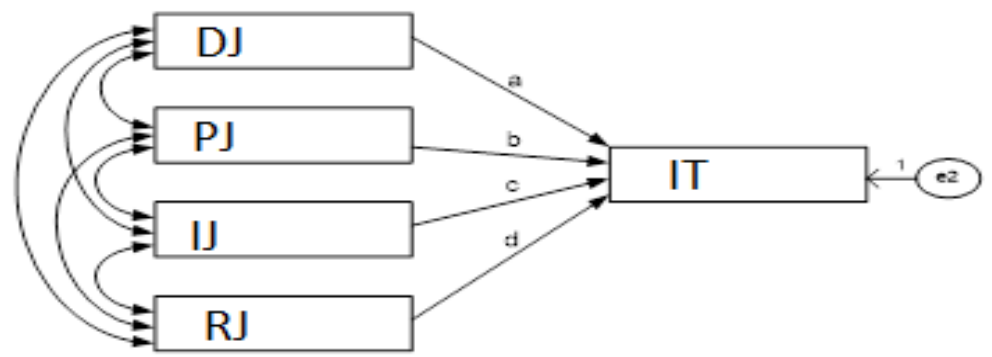

Figure 4. Conceptual model with significant path coefficient

Taking this as a starting point, the conceptual regression model (Figure 4) was formed to determine whether the organizational influence tactics used by administrators significantly predict the perception scores of distributive justice, procedural justice, interactional justice and rectificatory justice and the results of the regression model have been presented below (Figure 5 and Table 6).

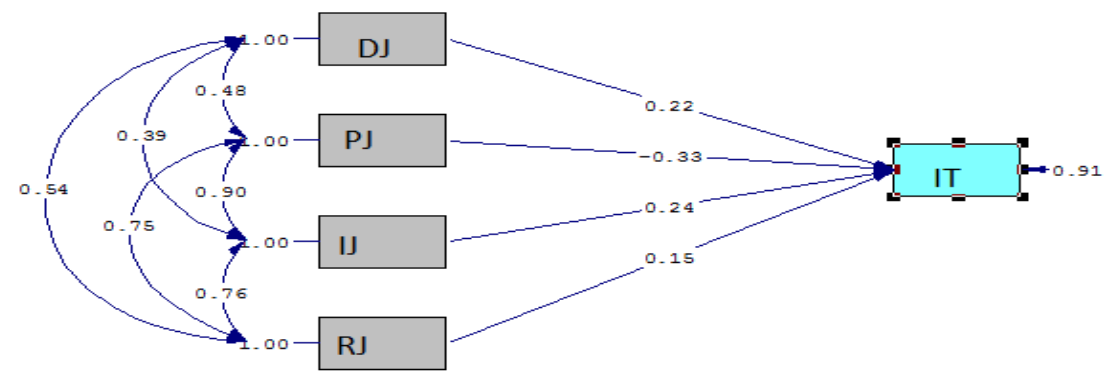

Chi-Square $=0.00, d f=0$, P-value $=1.00000$, RMSEA $=0.000$

Figure 5. The Standardized Regression Values of the Regression Model

As it can be seen in Figure 5, the standardized regression values of the regression model's perception scores of distributive justice, procedural justice, interactional justice and rectificatory justice in accordance with the 
organizational influence tactics used by administrators have been given. The relative order of significance of variables predicted in accordance with the standardized regression values on organizational influence tactics are procedural justice $(-0,33)$, distributive justice $(0,24)$, interactional justice $(0,22)$ and rectificatory justice $(0,15)$.

Table 7.

Organizational Influence Tactics of Administrators, Regression Model Formed Organizational Justice Types

\begin{tabular}{lccc}
\hline Regression Model 1 & B & $\beta$ & $t$ \\
\hline IT (D) <--- DJ (P) & 0,73 & 0,22 & 3,18 \\
IT (D) <--- PJ (P) & $-0,62$ & $-0,33$ & $-2,42$ \\
IT (D) <--- IJ (P) & 0,51 & 0,24 & 1,72 \\
IT (D) <--- RJ (P) & 0,46 & 0,15 & 1,57 \\
\hline
\end{tabular}

$* * \mathrm{P}<.01 * * \mathrm{P}<, 05,(\mathrm{P})=$ Predictive,$(\mathrm{D})=$ Dependent

When we take a look at the standardized regression significance $(\beta)$ obtained from the regression model in Table 6 and non-standardized regression significance in Table 6 (B) and the $P$ and $t$ values, it can be seen that in predicting the organizational influence tactics, primarily distributive justice (DJ) $(\mathrm{B}=0,73, \beta=0,22, \mathrm{P}<0,05, \mathrm{t}>1,96)$ and procedural justice (PJ) (SA) $(\mathrm{B}=-0,62, \beta=-0,33, \mathrm{P}<0,05, \mathrm{t}>1,96)$ are effective. It is observed that these two variables significantly predict the organizational influence tactics and are effective in the use of organizational influence tactics. When interactional justice (IJ) $(\mathrm{B}=0,51, \beta=0,24, \mathrm{P}>0,05, \mathrm{t}<1,96)$ and rectificatory justice $(\mathrm{RJ})(\mathrm{B}=0,46, \beta=0,15, \mathrm{P}>0,05, \mathrm{t}<1,96)$ are considered together with the other two variables, it is seen that these do not directly predict influence tactics in a significant manner.

Therefore, the Path between rectificatory justice CJ (D) <--- IJ(P) which does not have a statistically significant effect on organizational influence tactics and has the smallest regression values has been equated to 0 , a second regression model has been formed and the new regression model 
146 Kuru \& Cinkir - Relation between School Managers and Teachers Downward and Upward Influence Tactics and Organizational Justice

has been tested again. Table 7 below shows regression model 1 and the $\mathrm{X}^{2}$, RMSEA, CFI and SD values related to the newly formed regression model.

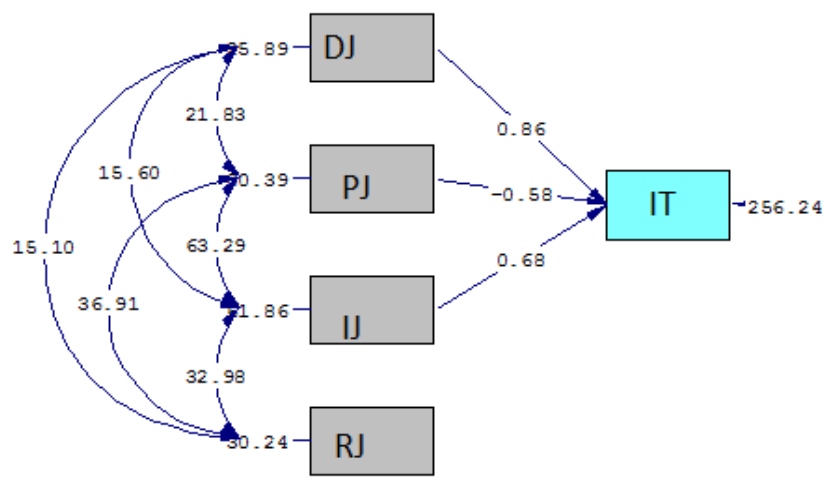

Chi-Square=2.46, df=1, P-value=0.11649, RMSEA=0.072

Figure 6. The Standardized Regression Values of the Regression Model

As it can be seen in Figure 6, after the Path between rectificatory justice and interactional justice has been equated to 0 , the standardized regression values of the regression model's perception scores of distributive justice, procedural justice and interactional justice have been given. According to the standardized regression values, the relative order of significance of predictive variables on organizational influence tactics are distributive justice $(0,86)$, interactional justice $(0,68)$ and procedural justice $(-0,58)$.

Table 8.

Resulting fit indices for regression model

\begin{tabular}{lccccccc}
\hline Regression Model & $\mathrm{X}^{2}$ & $\mathrm{sd}$ & $\mathrm{p}$ & $\mathrm{CFI}$ & $\mathrm{RMSEA}$ & $\Delta \mathrm{X}^{2}$ & $\Delta \mathrm{SD}$ \\
\hline 1.Model (Regression Model) & 0,00 & 0,00 & 1 & 1,00 & 0 & & \\
2.Model (c path =0) & 2,46 & 1 & 0,11 & 1,00 & .072 & 2,46 & 1 \\
\hline
\end{tabular}


In Table 8. above, the two regression models have been tested with the chi-square test and when the optimality concordance index values of the second regression model are analyzed, it has been seen that the second model is an acceptable model. It has been observed that rectificatory justice does not have a direct effect on the organizational influence tactics. It is seen that the other three variables explain $8 \%$ of the organizational influence tactics. According to the results of the regression analysis in the Path analysis, the regression equality (mathematical model) related to the prediction of the organizational influence tactics has been presented below.

Table 9:

Organizational influence tactics of administrators, the regression equality (mathematical model) formed organizational justice

$\begin{array}{cccccc}\text { IT }= & \begin{array}{c}0,86 \\ * \mathrm{DJ}\end{array} & -0,58 * \mathrm{PJ} & +0,68 * \mathrm{IJ} & \begin{array}{l}\text { Standard } \\ \text { Errors }=\end{array} & 256,24, \quad \mathrm{R}^{2}=0,078 \\ \begin{array}{c}\text { Standard } \\ \text { Errors }\end{array} & \begin{array}{c}(0,22 \\ )\end{array} & (0,26) & (0,28) & & (21,69) \\ \text { t value } & 4,01 & -2,25 & 2,44 & 11,81\end{array}$

Administrators' organizational justice types distributive justice and interactional justice affect organizational influence tactics in a positive manner and procedural justice affects organizational influence tactics in a negative manner. $86 \%$ of organizational influence tactics is explained by distributive justice, $68 \%$ by interactional justice and $58 \%$ by procedural justice. These three variables together explain $8 \%$ of the organizational influence tactics. According to these results, it can be stated that it has "little" effect in explaining distributive justice, procedural justice and organizational influence tactics.

In the Dulebohn and Ferris (1999) study on the relationship between administrators and employees, organizational influence tactics and procedural justice, it has been concluded that there is a positive relationship $(0,22)$ between organizational influence tactics and procedural justice. The difference concerning the relationship between organizational influence tactics and procedural justice and the results of this study can be due to 
analyzing the study in terms of performance evaluation. However, the relationship of procedural justice with organizational influence tactics in Dulebohn and Ferris' study (1999) is very close to the relationship obtained in this study $(0,19)$. Dulebohn and Ferris' (1999) study is important in terms of supporting the results of this study. Dulebohn (1995), in his study on administrators and employees has concluded that there is a relationship of 0,19 between the procedural justice perceived by employees and organizational influence tactics. However, he has reported that there is no relationship between distributive justice and organizational influence tactics.

\section{Conclusions}

Distributive, procedural and interactional justices seem to be the organizational justice types used by the teachers. There is a positive lowlevel relationship between the organizational influence tactics and rectificatory justice. Rectificatory justice has no direct influence over the organization of the influence tactics when we include prediction of organizational influence tactics with other variables and errors in measuring.

Distributive, procedural and interactional justices are the organizational justice types most used by the managers. There is a positive low-level relationship between the organizational influence tactics and rectificatory justice and interaction justice. Rectificatory justice has no direct influence over the organization of the influence tactics when we include prediction of organizational influence tactics with other variables and errors in measuring.

\section{Funding}

This study was supported by Ankara University Coordination Unit of Scientific Research Projects (Project Code: 12B 5250001). 


\section{References}

Alonso, S. (2010). Social Influence Tactics Used By Physicians: An

Empirical Study. Florida: Unpublished Doctoral's Thesis. University Of Miami.

Bacharach, B., \& Lawler, J. (1980). Power And Politics In Organizations.

San Fransisco: Jessey-Bass Pub.

Bass, B. M. (1990). Bass \& Stogdill's Handbook Of Leadership: Theory,

Research, And Managerial Applications. New York: Free Press.

Basaran, İ. (2000). Yonetım (3. Basım). Ankara: Feryal Matbaası.

Bayrak, S. (2000). Yonetımde Ihmal Konusu Olarak Guc Ve Guc Yonetımı-

1. Suleyman Demirel Universitesi İktisadi ve İdari Bilimler

Fakultesi Dergisi(2), 21-34.

Bradway, L. (2002). Effects Of Upward Influence Tactics On Coworkers: An

Equity Perspective. Chicago : University Of Illinois.

Bursalıglu, Z. (2002). Okul Yonetiminde Yeni Yapı ve Davranıs.(12.

Basım). Ankara: Pegem A Yayıncilik.

Dawis, K. (1984). Isletmede Insan Davranısı.(2. Baskl). (Cev.Kemal Tosun et al) Istanbul: İ.U.İsletme Fakultesi Enstitusu Yayını.

Dohlen, H. (2012). Teacher Leadership Behaviors and Proactive Influence

Tactics In North Carolina Public School. Carolina, USA:

Unpublished Doctoral's Thesis. Western Carolina University .

Dulebohn, J. (1995). Social Influence and Organizational Justice In

Employee Reactions To Performance Appraisals. Urbana, Illinois:

Unpublished Doctoral's Thesis. University Of Illinois At Urbana-

Champaign.

Dulebohn, J., \& Ferris, G. (1999). The Role Of Influence Tactics In

Perceptions of Performance Evaluation' Fairness. Academy of

Management Journal, 42(3), 288-303.

Duyar, I., Aydın, I., \& PehlIvan, Z. (2009). Analyzing Principal Influence

Tactics From A Cross-Cultural Perspective: Do Preferred

Influence Tactics And Targeted Goals Differ By National Culture?

A. W. Wiseman., \& A. W. (Editorler), Educational Leadership: 
150 Kuru \& Cinkir - Relation between School Managers and Teachers Downward and Upward Influence Tactics and Organizational Justice

Global Contexts And International Comparisons, 11,191-221).

Bingley, UK: Volume 11 Of The Book Series: International Perspectives On Education And Society.

French, T., \& Raven, B. (2001). The Basis Of Social Power (1959). I.

Asherman, \& S. Asherman (Editorler), The Negotiation Source

Book (2. Edt.) (S. 61-73). Amherst: HRD Press.

Friedrich, T. (2010). Leadership In Teams: Investigating How Team

Network Impact The Use Of Influence, Unpublished Doctoral's

Thesis. Oklohoma: University Of Oklohoma.

Greenberg, J. (1990). Organizational Justice: Yesterday, Today and

Tomorrow. Journal Of Management, 16(2), 399-432.

Greenberg, J., \& Baron, R. (1993). Behavior In Organization. New York: A.

Division Of Simon And Schuster.

Hales, C. (1993). Managing Through Organization: The Management Process, Forms Of Organization and Work Of Managers. New York: Routledge.

Hatch, J. (1997). Organization Theory Modern, Sysbolic And Posmodern

Perspectives. Great Britain: Oxford University Press.

Hoy, W., K. \& Miskel, G. (2010). Egitim Yonetimi ve Uygulama Teori ve Arastırma. (S. TuranCev. Edi.) Ankara: Nobel Yayın.

Hunt, J. (1994). Yonetici İcin Orgut İcindeki Davranıs Kılavuzu. (M.

Odman, Cev.) Ankara: Oteki Yayınları.

Isbası, J. (2000). Calısanların Yonetıcilerine Duydukları Guvenin ve

Orgutsel Adalete Ilıskn Algllamalarının Orgutsel Vatandaslık

Davranısinın Olusumundakı Rolu: Bir Turizm Orgutunde

Uygulama. Antalya: Yayınlanmamıs Yuksek Lısans Tezi, Akdeniz Universitesi Sosyal Bilimler Enstitusu.

Kipnis, D., \& Schmidt, S. (1999). Profiles Of Organizational Influence

Strategies (POIS): Influencing Your Subbordinates (Form S). San

Diego, CA: University Associates, Inc.

Machiavelli (1998). Hukumdar. (H. K. Karabulut, Cev.) Istanbul: Sosyal

Yayınlar1. 
Massey, G., \& Dawes, P. (2006). Manifest Influence and Interpersonal Trust On Working Relationships Between Marketing Managers and Sales Managers. University Of Wolverhampto: Working Paper Series Wp003/06 ISSN Number 1363-6839.

Massie, J. (1983). İsletme Yonetimi. (S. V. Digerleri, Cev.) Eskisehir: Baytas Yayınc1lik, A.S.

Mechanic, D. (1962). Sources of power of lower participants in complex organizations. Administrative Science Quarterly, 7, 349-364.

Mintzberg, H. (1983). Power In Around Organization. Nj: Prentice Hall: Englewood Cliffs.

Moorman, R. H. (1991). Relationship Between Organizational Justice and Organizational Citizenship Behaviors: Do Fairness Perceptions Influence Employee Citizenship? Journal Of Applied Psychology, 76(6), 845- 855.

Ozmen, O., Arbak, Y., \& Ozer, S. (2007). Adalete Verılen Degerin Adalet Algiları Uzerindeki Etkısının Sorgulanmasına Ilıskın Bır Arastırma. Ege Akademık Bakıs, 7(1), 17-33.

Pfeffer, J. (1999). Guc Merkezli Yonetim: Orgutlerde Politika ve Nufuz. (E. Ozsayar, Cev.) Istanbul: Imprint Istanbul, Boyner Holding Yayınlar1.

Polat, S. (2008). Eğitim politikalarının sosyal adalet açısından sonuçşarı konusunda yönetici ve ögrretmen görüşleri. Ankara Üniversitesi Eğitim Bilimleri Enstitüsü. Yayımlanmamış Yüksek Lisans Tezi.

Rollinson, D. (2002). Organizational Behaviour and Analysis. New York: Prentice Hall Financial Times.

Salancik, G. R., \& Pfeffer, J. (1974) The Bases and Use Of Power In Organizational Decision Making: The Case of A University. Administrative Science Quarterly, 19, 453-473

Sarıtas, M. (1991). Mudurlerinin Etki Surecine ılıskın Yeterlıklerı. Ankara:

Yayımlanmamıs Doktora Tez1, Hacettepe Universitesi, Sosyal Bilimler Enstitusu. 
152 Kuru \& Cinkir - Relation between School Managers and Teachers Downward and Upward Influence Tactics and Organizational Justice

Schriesheim, C. A., \& Hinkin, T. R. (1990). Influence Tactics Used By Subordinates: A Theoretical And Empirical Analysis and Refinement Of The Kipnis, Schmidt and Wilkinson Subscales. Journal Of Applied Psychology., 75, 246-257.

Thompson, B. (2004). Explaratory And Confirmatory Factor Analysis Understanding Concepts and Aplications. Washington, DC: American Pscholojical Associations .

Weber, M. (1947). The Theory Of Social And Economic Organization. Glencoe: Free Press.

Yamaguchi, I. (2005). Interpersonal Communication Tactics And Procedural Justice For Uncertainty Management Of Japanese Workers. Journal Of Business Communication, 42(2), 168-194.

Yamaguchi, I. (2009). Influences Of Organizational Communication Tactics On Trust With Procedural Justice Effects: A Cross-Cultural Study Between Japanese And American Workers. International Journal Of Intercultural Relations, 33, 21-31.

Yang R. \& Cervero R.M. (2001) Power and influence styles in programme planning: relationship with organizational political contexts. International Journal of Lifelong Education, 20:4, 289-296, DOI: 10.1080/02601370110048827

Yaylac1, G. (2006). Organizasyonlarda Kisilerarası İliskilerde Etki Taktikleri ve Kullanımına İliskin Literatür Calısması. Bilgi Turk Dunyası Sosyal Bilimler Dergisi, 36, 93-112.

Yukl, G., \& Tracey, B. (1992). Consequences of Influence Tactics Used With Subordinates, Peers and The Boss. Journal Of Applied Psychology., 77, 525-535.

Yukl, G. (2010). Leadership In Organization. 7th Edition. New Jersey: Pearson. 


\begin{abstract}
Saadet Kuru Cetin is an Assistant Professor in the Department of Educational Management, Supervision, Planning and Economics at Mugla Sitki Kocman University, Turkey. Her research interests include organizational behavior, ethics and classroom management.

Contact Address: Muğla Sitkı Koçman University Faculty of Education (T Block) 48000 Kötekli Campus / MUĞLA TURKEY

E-mail: saaddet@gmail.com
\end{abstract}

Sakir Cınkır is associate professor of Educational Management and Policy at Ankara University, Turkey. He received his doctorate from University of Leeds, School of Education. England. His work on school management, management problems and organizational behavior.

Contact Address: Ankara Üniversitesi Eğitim Bilimleri Fakültesi 06590-Cebeci-ANKARA

E-mail: cinkir@education.ankara.edu.tr 